\title{
Higher Education in a scheme of Social Responsibility towards the change of paradigm
}

\section{La Educación Superior en un esquema de Responsabilidad Social hacia el cambio de paradigm}

\author{
MORÁN-BRAVO, Luz del Carmen ${ }^{1 * \dagger}+$, DE SAMPEDRO-POBLANO, Héctor Manuel ${ }^{1}$, OSORIO- \\ GÓMEZ, Ricardo ${ }^{2}$ and HERRERA-SÁNCHEZ, Gustavo ${ }^{1}$ \\ ${ }^{1}$ Universidad Tecnológica de Puebla \\ ${ }^{2}$ Instituto Tecnológico de Puebla
}

ID $1^{\text {st }}$ Author: Luz del Carmen, Morán-Bravo / ORC ID: 0000-0002-7096-2075, Researcher ID Thomson ID: G-2686-2018, arXiv Author ID: XVRUS3-JP9XUY, CVU CONACYT ID: 75419

ID $1^{\text {st }}$ Coauthor: Héctor Manuel, De Sampedro-Poblano / ORC ID: 0000-0002-9235-9007, Researcher ID Thomson: Q8174-2018, arXiv Author ID: V9HG4K-7ZVVF3, CVU CONACYT ID: 548477

ID $2^{\text {nd }}$ Coauthor: Ricardo, Osorio-Gómez / ORC ID: 0000-0002-4478-8333, CVU CONACYT ID: 75417

ID $3^{\text {rd }}$ Coauthor: Gustavo, Herrera-Sánchez / ORC ID: 0000-0001-5276-5062, Researcher ID Thomson: F-6595-2018, arXiv Author ID: herreragh, CVU CONACYT ID: 459805

DOI: $10.35429 /$ EJS.2019.11.6.20.28

Received September 10, 2019; Accepted December 15, 2019

\section{Abstract}

Technological development has brought about significant positive and negative global changes, including environmental degradation, human rights, the concentration of wealth, and increased poverty. That as a whole has resulted in the loss of human consciousness towards care and responsibility for the environment and sustainability. In some cases, out of ambition and in others out of necessity. The present study has the objective of showing that in the majors of Higher Technical University and Engineering, the study plans have been gradually incorporating into their plans and programs subjects that promote awareness of Social Responsibility (SR) among the university community, an effort that can be strengthened with other tools such as the NMX-SAST-ISO:26000 Standard, which is a guide to lead cross-cutting strategies and systematize the actions implemented by Higher Education Institutions (IES). In order to carry out this research, we used the longitudinal comparative method. The results of this research are divided into two moments; in the 2009 study plans in which they only incorporated up to 20 percent of topics related to Social Responsibility in the Business and Administration plans of the Technological University Subsystem. In a second moment, the 2017 study plans were analyzed, in which a significant advance is observed since 32 and 48 percent respectively of the study plan is incorporated into the business and administration subject sheets. To complement the research, a survey was carried out with the students in 2018 regarding the level of knowledge and management of concepts related to Social Responsibility, in which 75 percent of the students interviewed have at least a general idea of the subject.

ISO26000 Standard, Education, Social Responsibility, Technological Universities

\begin{abstract}
Resumen
El desarrollo tecnológico ha logrado grandes cambios globales positivos y negativos, entre ellos se encuentra el deterioro ambiental, los derechos humanos, concentración de la riqueza y mayor pobreza. Que en conjunto se ha traducido en la pérdida de conciencia humana hacia el cuidado y responsabilidad sobre el medio ambiente y la sustentabilidad. En algunos casos por ambición y en otros por necesidad. El presente estudio tiene como objetivo mostrar que en las carreras de Técnico Superior Universitario e Ingenierías, los planes de estudio poco a poco han ido incorporando a sus planes y programas de estudio temas que fomenten la concientización de la Responsabilidad Social (RS) entre la comunidad universitaria, esfuerzo que se puede fortalecer con otras herramientas como la Norma NMX-SAST-ISO:26000, siendo esta una guía para orientar las estrategias transversales y sistematizar las acciones implementadas por las Instituciones de Educación Superior (IES). Para realizar la presente investigación se utilizó el método comparativo longitudinal, los resultados de esta investigación se dividen en dos momentos; en los planes de estudio de 2009 donde solo incorporaron hasta 20 por ciento de temas relacionados con la Responsabilidad Social en los planes de Negocios y Administración del Subsistema de Universidades Tecnológicas. En un segundo momento se analizaron los planes de estudio de 2017 donde se observa un avance significativo ya que se incorporan a las hojas de asignatura de negocios y administración entre el 32 y 48 por ciento respectivamente del plan de estudios, para complementar la investigación se realizó un sondeo a los alumnos en 2018 respecto al nivel de conocimiento y manejo de conceptos relacionados con la Responsabilidad Social dando como resultado que el 75 por ciento de los alumnos entrevistados tienen al menos una idea general del tema.
\end{abstract}

Norma ISO26000, Educación, Responsabilidad Social, Universidades Tecnológicas

Citation: MORÁN-BRAVO, Luz del Carmen, DE SAMPEDRO-POBLANO, Héctor Manuel, OSORIO-GÓMEZ, Ricardo and HERRERA-SÁNCHEZ, Gustavo. Higher Education in a scheme of Social Responsibility towards the change of paradigm. Journal-Spain. 2019. 6-11: 20-28

*Correspondence to Author (lcmoran.utpuebla@gmail.com)

$\uparrow$ Researcher contributing as first author. 


\section{Introduction}

The recomposition of the world economic model and the technological changes bring beneficial results to society, but also society is more aware of the deterioration of the environment, as a result of the excessive ambition of capitalism. Hence, in recent decades there are demonstrations and movements in favor of the care and conservation of natural resources, so it is urgent to change society towards a responsible behavior in order to achieve sustainable development, for which organizations seek strategies that allow a better coexistence between citizens, government, businesses, consumers, industry, workers, NGOs, universities, academia, and other stakeholders.

\section{Background}

At the international level since 2000, the United Nations Global Compact (UN, 2018) calls on companies worldwide to align their operations and strategy based on universal principles in the areas of environment, anti-corruption, human rights among the most important objectives, where approximately 135 countries participated in a voluntary initiative of corporate responsibility. To this end, the Management Model of the UN Global Compact's labor principles was created to guide companies in formalizing, defining, implementing, measuring, and evaluating a sustainability strategy.

Later in the International Organization for Standardization (ISO) with the participation of 90 countries and 40 organizations, formed in six groups of stakeholders including consumers, government, industry, workers, nongovernmental organizations (NGOs), services, support, research, academia, and others worked in just over five years to make agreements and achieve balanced participation between groups, countries, and stakeholders, and under the methodology and format ISO was integrated, approved and published the ISO 26000:2010, in Geneva Switzerland.

In Mexico also worked on the issue through the Mexican Institute of Standardization (IMNC) who is the entity authorized to develop, update, issue and cancel Mexican standards, including the NMX-SAST-26000-IMNC.
Which involved the Technical Committee of National Standardization Systems Administration of Safety and Health at Work, IMNC/CONTENNSASST, Subcommittee 4 (IMNC, 2011) in the development of the guide to Social Responsibility participated 42 organizations from different productive sectors, businesses, universities, public and private institutions, and NGOs; This subcommittee worked together with its counterparts in other countries to integrate the ISO 26000 Social Responsibility Guide.

The ISO 26000 is a voluntary standard, it is a guide of postulates and recommendations, about definitions, principles and related materials, referred to the Social Responsibility, unlike other standards it is not certifiable since it does not establish requirements to develop a management system.

The standard provides guidance on the principles that govern Social Responsibility. It is a guide that allows the recognition of Social Responsibility, the involvement with all stakeholders, including educational institutions, businesses, and government.

The concept of Social Responsibility (SR) has been addressed with greater relevance, from 2014, this being the thematic axis of the World Conference on Education, which had as its central theme Sustainable Development (UNESCO, 2014) so that higher education acquired an important role regarding the issue of Social Responsibility and sustainable development, incorporated by the Mexican government as part of public policy.

Given such an approach, it is necessary to develop other pedagogical models or actions that succeed in making university students aware of a scheme of values that allows them to change their behavior in a socially responsible university and that, upon graduating, also transfer the philosophy to companies under the concept of social responsibility, actions that should be formalized in the maps and study programs. The present study aims to show the results of comparative analysis between the plans and sheets of subject 2009 and 2017 of the area of administration and business that promote social responsibility as part of the professional skills of students; among them are a) engineering development and business innovation 2009, b) Technical University (TSU) in Administration Human Resources area 2009.

MORÁN-BRAVO, Luz del Carmen, DE SAMPEDRO-POBLANO, Héctor Manuel, OSORIO-GÓMEZ, Ricardo and HERRERASÁNCHEZ, Gustavo. Higher Education in a scheme of Social Responsibility towards the change of paradigm. Journal-Spain. 2019 
c) Technical University (TSU) Business Development Marketing area 2009 and TSU in Administration Human Capital area 2017 and TSU Business Development Marketing area (2017).

\section{Approach to the problem}

Today, people's needs are different, other than economic needs, they belong to another market segment, more demanding with other consumption requirements based on the care and conservation of the environment as a lifestyle that has gradually spread throughout the world, this being a trend among the population that is showing more and more responsibility to their society and the environment around them. Paraphrasing Cicero, who from ancient times emphasized the duties that are natural to man, they give rules to lead an orderly and honest life. At the same time, the law and justice allow for equal rights of citizens; likewise, the rules guide and orient people, organizations, markets to facilitate coexistence and reach agreements in a scheme of social responsibility.

Social Responsibility is a commitment, obligation, and duty that individuals, members of a society or company have to achieve a fairer society and protect the environment voluntarily. The issue of Social Responsibility has taken significant importance in recent decades worldwide as a project and initiative of the United Nations that aims to promote universal values and responsible business in the world. In our country since 2005, the Mexican government in its three levels of government incorporated into their programs policies and actions related to work in the region of the Global Compact (GC) (ECLAC, 2019) require further impetus and strengthening for which it needs the participation of government, companies, and Institutions of Higher Education who carry out change in an orderly, gradual and systematic way. As Senge (1992,p,91) states "systematic thinking is a framework to see interrelations instead of things, to see patterns of change instead of static snapshots" in this sense education is one of the primary agents of change in the behavior and transformation of individuals and societies (Munch,2018). Faced with such changes and demands, the question arises: What are Higher Education Institutions in Mexico doing to promote Social Responsibility? When the objective of Social Responsibility is to contribute to sustainable development.
Because of this need, this research was carried out to analyze, according to the curricular maps of the Division of Business and Administration, the cases in which subjects related to Social Responsibility are taught.

Likewise, a pilot diagnosis was carried out during September-December 2018 among the students of Higher Technical University, Human Resources (30 students), business development and marketing (32) and Engineering, development and business innovation (60), regarding the knowledge they have on the subject of Social Responsibility. It was concluded that 75 percent of the students have basic knowledge regarding Social Responsibility and related topics such as being in harmony with the environment, human rights, ethics and governance, transparency, orderly production practices, and green companies that say that companies should be committed to harmonizing economic capital. It was observed that the majority of students know the concept; however, they lack tools, strategies, and fundamentals on the implementation of actions that improve the conditions of their environment.

\section{The importance of education and social responsibility}

The technological advances have allowed significant transformations, eliminating frontiers in terms of information in real time, new needs arise, professions appear and disappear, life and consumption patterns, that is, we live in constant change. However, not everything is positive. It has some inconveniences and economic, social, political, cultural, demographic, legal and environmental implications, the latter being the factor with the greatest impact that should be considered as a starting point for raising awareness among the population towards the rescue, conservation, and care of nature, which is the source of life.

Hence the importance of seeking means and strategies that allow for the involvement of the entire population through education, as Delors would say (1997,p.9), "Education is an indispensable instrument for humanity to progress towards the ideals of peace, freedom and social justice." Today we must prepare children and young people who will transform the world of tomorrow. 
Surely many of them will be the ones who will lead companies and with them will consciously seek to improve the relationship with customers, suppliers, government, workers, other companies in order to achieve positive change in the community and make a fairer world (op cit). Education allows people to become aware of themselves and their environment, inviting them to play their social role in the workplace and the community. Therefore, social responsibility must go hand in hand with education from childhood within the family, with the promotion and practice of values, reaffirming them at school.

Education refers to the process through which man is formed and led to his plenitude. Another concept refers to the work of formation that adults exercise on youth and in the strictest sense, it focuses on the task that schools and universities carry out (Maritain, 2008) to make better people. However, Higher Education has been dedicated to developing technical competencies making the graduates competent professionals, but with significant deficiencies of values and ethics, actions that are observed in the impact of the work and social environment. For this reason, as of 2014, Higher Education should take on a different role, aimed at incorporating the subject of Social Responsibility and/or sustainable development into the study plans and designing some subjects as good intentions but in an isolated manner.

\section{Material and method}

In this work, the subsystem of Technological Universities is taken as a reference, and for its analysis, three Educational Programs were reviewed, in which professionals in administration and business are trained. To carry out the present study, we used the longitudinal comparative method ( Münch 2018) and the use of qualitative and quantitative data was made in two stages. In the first one, we made a documentary review of the topic of Social Responsibility for the plans and educational programs 2009 and 2017. We identified those subject sheets containing topics related to social responsibility. Then we carried out a comparative analysis between the 2009 and 2017 curricula in order to identify the subject sheets, the contents of which promote and develop professional competencies with an orientation towards social responsibility.
In a second stage, information was obtained with the engineering students, TSU Marketing and TSU Human Capital through a survey (Rojas, 2016) to find out the students' opinion regarding the level of knowledge and use of concepts related to Social Responsibility and its application in the work and tasks they developed during their training.

\section{Results}

Once the analysis of the Curricular Map of three educational programs of Business and Administration belonging to the subsystem of Technological Universities and the subject sheets of the study plan and application of the survey was done, we found the following results: In the integral formation of the students of the model of Technological Universities, all of them make the practical stay during the last fourmonth period (sixth for TSU and eleventh for the Engineering Plan) in a public or private company where they put into practice what they have learned in the university; when analyzing the plans of the three curricula of 2009, we found that the TSU curriculum in Human Resources Management is the one that incorporated the least amount of topics related to Social Responsibility since it was observed that only 19 percent of the total number of course sheets incorporated related topics, and the other two programs incorporated 21 and 23 percent of the total number of courses.

As of 2009, the study plans of the business and administration area incorporated some topics related to Social Responsibility in some subjects but in an isolated manner, which means that until that moment it was not relevant even though there were already international agreements between the Mexican government and the United Nations, for which programs, policies and actions related to work in the Global Compact (GC) region (ECLAC, 2019) were implemented. On the other hand, the 2017 study plans were reviewed and updated by the General Coordination of Technological and Polytechnical Universities (CGUT) of the TSU Administration Human Capital area and TSU Business Marketing area programs, showing a significant change of between 48 and 32 percent respectively in terms of the incorporation of more subjects to the study plan related to Social Responsibility in each of the SPs analyzed.In the case of Engineering in Development and Business Innovation it remains the same because the study plan has not been updated by CGUT, see table 2 and 3. 


\begin{tabular}{|c|c|c|c|c|}
\hline $\begin{array}{l}\text { Name of } \\
\text { Educational } \\
\text { Program }\end{array}$ & $\begin{array}{c}\text { Curriculu } \\
\text { m } \\
\text { September } \\
2009\end{array}$ & $\begin{array}{l}\text { Name of } \\
\text { Educational } \\
\text { Program }\end{array}$ & $\begin{array}{c}\text { Curriculu } \\
\text { m } \\
\text { September } \\
2017\end{array}$ & $\begin{array}{l}\text { Practical } \\
\text { stay }\end{array}$ \\
\hline $\begin{array}{l}\text { TSU in } \\
\text { Administratio } \\
n\end{array}$ & \begin{tabular}{|l|}
$19 \quad \%$ \\
includes \\
the subject \\
of SR
\end{tabular} & 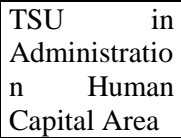 & $\begin{array}{l}48 \quad \% \\
\text { includes } \\
\text { the subject } \\
\text { of SR }\end{array}$ & $\begin{array}{l}\text { Companie } \\
\mathrm{s} \\
\text { Public }\end{array}$ \\
\hline $\begin{array}{l}\text { Human } \\
\text { Resources } \\
\text { Area }\end{array}$ & \begin{tabular}{|l|}
21 \\
includes \\
the subject \\
of SR
\end{tabular} & $\begin{array}{l}\text { TSU } \\
\text { Business } \\
\text { Marketing } \\
\text { Area }\end{array}$ & $\begin{array}{l}32 \quad \% \\
\text { includes } \\
\text { the subject } \\
\text { of SR }\end{array}$ & $\begin{array}{l}\text { Private } \\
\text { NGO }\end{array}$ \\
\hline $\begin{array}{l}\text { TSU } \\
\text { Business } \\
\text { Marketing } \\
\text { Area }\end{array}$ & \begin{tabular}{|l|}
$23 \quad \%$ \\
includes \\
the subject \\
of SR
\end{tabular} & $\begin{array}{l}\text { Development } \\
\text { Engineering } \\
\text { and Business } \\
\text { Innovation } \\
\end{array}$ & No change & \\
\hline
\end{tabular}

Table 1 Distribution of the percentage of the study plan that incorporates subjects to promote Social Responsibility

Source: Elaboration with data taken from CGUT 2009 and 2017 curricula

As can be seen in Table 2, in all areas of knowledge of the curriculum of the Higher Technician in Management area Human Capital 2017, at least one subject includes topics related to Social Responsibility and sustainable development. However, in the second and third quarters, related topics are included in 7 subjects of each quarter. Likewise, of the total of 41 subjects that make up the curriculum, 20 of them include topics related to the promotion of Social Responsibility and sustainable development, it is worth noting that all the subject sheets of the curriculum are designed with the model of competencies: knowledge, know-how and howto-be, in which ethics and human values are promoted.

\begin{tabular}{|c|c|c|}
\hline $\begin{array}{c}\text { Area of } \\
\text { knowledge }\end{array}$ & Subjects & $\begin{array}{l}\text { Estadía } \\
\text { práctica }\end{array}$ \\
\hline $\begin{array}{l}\text { Basic } \\
\text { Sciences }\end{array}$ & $\begin{array}{l}\text { Computing, Financial } \\
\text { Mathematics, Statistics applied } \\
\text { to Administration }\end{array}$ & $\begin{array}{l}\text { Application of } \\
\text { the } \\
\text { competences }\end{array}$ \\
\hline \begin{tabular}{|l|} 
Technology \\
Training
\end{tabular} & 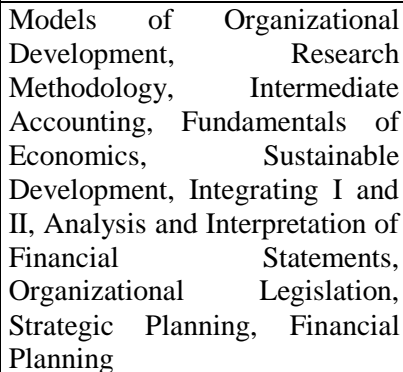 & $\begin{array}{l}\text { developed } \\
\text { Being } \\
\text { Knowledge } \\
\text { Know-how }\end{array}$ \\
\hline \begin{tabular}{|l|} 
Languages \\
and Methods
\end{tabular} & $\begin{array}{l}\text { Oral and Written Expression I } \\
\text { and II }\end{array}$ & \\
\hline \begin{tabular}{|l|} 
Management \\
Skills \\
\end{tabular} & $\begin{array}{l}\text { Socio-cultural Training I, II, III } \\
\text { and IV }\end{array}$ & \\
\hline \begin{tabular}{|l|}
$\begin{array}{l}\text { Professional } \\
\text { skills }\end{array}$ \\
\end{tabular} & Social Responsibility & \\
\hline
\end{tabular}

Table 2 List of subjects teaching sustainable development and social responsibility TSU Human Capital Area

Source: Elaboration with data taken from CGUT 2017 curricula
On the other hand, we also analyzed the curriculum of the Higher Technical University Business Marketing area, composed of 40 subjects, in this major we can see that in three quarters the subject sheets are included in 25 percent. It is important to mention that in the fourth four-month period, 50 percent of the subjects include SR-related topics, and on average, the study plan considers 32 percent of the total (see Table 3).

\begin{tabular}{|c|c|c|}
\hline $\begin{array}{c}\text { Area of } \\
\text { knowledge }\end{array}$ & Subjects & Estadía práctica \\
\hline Basic Sciences & & \multirow{5}{*}{$\begin{array}{l}\text { Application of } \\
\text { the competences } \\
\text { developed } \\
\text { Being } \\
\text { Knowledge } \\
\text { Know-how }\end{array}$} \\
\hline $\begin{array}{l}\text { Technology } \\
\text { Training }\end{array}$ & $\begin{array}{l}\text { Market Research System I } \\
\text { and II , Labour } \\
\text { Legislation, Promotional } \\
\text { Mixture I, International } \\
\text { Marketing }\end{array}$ & \\
\hline $\begin{array}{l}\text { Languages and } \\
\text { Methods }\end{array}$ & $\begin{array}{l}\text { Oral and Written } \\
\text { Expression I and II }\end{array}$ & \\
\hline $\begin{array}{l}\text { Management } \\
\text { Skills }\end{array}$ & $\begin{array}{l}\text { Socio-cultural Training I, } \\
\text { II, III and IV }\end{array}$ & \\
\hline $\begin{array}{l}\text { Professional } \\
\text { skills }\end{array}$ & Social Responsibility & \\
\hline
\end{tabular}

Table 3 List of subjects that teach topics related to sustainable development and social responsibility of TSU Business Development Marketing Area in professional skills

Source: Elaboration with data taken from CGUT 2017 curricula

It is a great advance that educational programs include related topics to raise awareness among students and teachers, who are an important element for the transformation of society (Delors, 1997). Currently, all the curricula of Higher Education Institutions (HEI) incorporate topics related to sustainability and social responsibility.

Education is one of the most important means to carry out social transformations since it links individual, social, demographic, cultural, economic, political, scientific, legal and biotic elements, which as a whole become complex in the coexistence of human beings and social development. At the same time, the instances related to the evaluation of educational programs implement indicators that attend to the initiatives of UNESCO in 1992, with the objective of permeating the HEI with Social Responsibility, ethical commitment, environmental care and economic development (UN, 2015), as is the case of the Council for Higher Education Accreditation COPAES, AC. 
Which is the body or the superior instance accredited by the Mexican government to operate through accredited bodies, mechanisms of evaluation, systematic and voluntary follow up of the fulfillment of the university functions of the IES in a process of improvement through the fulfillment of criteria, indicators and standards of pertinence, and educational quality (COPAES, 2018) has incorporated into its evaluation indicators in the category Curriculum, subjects related to values and attitudes of professional ethics, knowledge about the economic, political and social environment, national and international, development of skills to work in multidisciplinary groups, promotion of quality culture, integrate knowledge about sustainable development, indicators that require attention by the IES, for which the latter must formally implement in their curricula issues and actions that lead to meet these requirements, but to the extent that the actions are systematized allowing transit to the awareness of the university community.

On the other hand, the participation of other actors such as the National Association of Accounting and Administration Faculties and Schools (ANFECA), as of 2015, is carrying out actions aimed at strengthening and promoting social responsibility among public and private HEIs through the awarding of a distinction called "University Social Responsibility," which aims to provide tangible evidence of the educational impact on the generation and application of organizational, environmental and social knowledge for sustainable human development (ANFECA), 2018), this award is valid, so it must be renewed every three years, from 2016 the IES participate in the evaluation process to achieve the award, in this process they managed to obtain the award 36 IES, for 2017 joined 15 more institutions, strategies that seek to systematize actions to promote the dissemination and awareness of the university community towards a culture of environmental care, ethical commitment, economic development to improve environmental conditions and community.

The companies do the same since they participate in evaluation processes where they are asked to comply with specific criteria to receive the Socially Responsible Company Distinction (ESR), a certificate granted by the Mexican Center for Philanthropy (CEMEFI) since 2001.
Which recognizes the brand and accredits the company to its workers, investors, customers and suppliers, authorities and society in general as an organization voluntarily committed to a socially responsible management as part of its culture, which are grouped into four strategic lines of the distinctive among them the ethics and corporate governance, quality of life in the company, the linkage and commitment to the community, care and preservation of the environment, currently in Mexico there are 1126 companies with this distinction (CEMEFI, 2019).

At present, Corporate Social Responsibility (CSR) is taking great importance at a global level. It has become a central policy where the main agents of change are people; in this regard, Bernardo Kliksberg says that CSR allows stability and improves the employment situation of employees, the business climate, but above all, generates trust with each other, is a win-win investment, we must include small businesses (MSMEs) that need training and work to change their culture, it is in this sector where HEIs have much to contribute from the awareness in the care of the environment, social development and economic aspects that surround us.

It should be noted that global companies have incorporated the concept into their practices, while governments (local, state and federal) have implemented issues such as accountability, transparency, gender equity (Moran, 2017) in theory programs aimed at this issue; however, their implemented actions are isolated and compliance with a "mandatory" regulation to promote social responsibility among the population.

\section{Discussion/Conclusion}

Given the importance that higher education institutions imply in the formation of their students on Social Responsibility, it is pending to analyze how future leaders will promote the development of society through the creation and formation of social capital. Due to the multiple needs that these institutions have, mainly the public ones on the economic supports, it can be a factor against to be limited and to fulfill the sense of Social Responsibility and critical towards the public and private entities, according to the codes and standards of the sustainable development. 
From the extension and diffusion in the institutions of higher education and the ethical formation of the students, efforts should be made so that this knowledge truly reaches society.

From the analysis of results, it can be said that Technological Universities, over time, have become more involved with Social Responsibility and have taken necessary but insufficient actions to achieve significant changes in the environment.

However, such strategies are not enough; a greater impulse and strengthening on Social Responsibility and sustainable development is required. The participation of all sectors is vital for change, government, companies, and Educational Institutions at all levels, including the level.

Higher Education Institutions are engines of change and have an essential role in the transformation and paradigm shift in the issue of doing business under a different approach towards cleaner economies in order to restore the damage caused to the environment, which is the result of economic activity. Currently, ANFECA has made its best effort to promote actions aimed at strengthening the issue of Social Responsibility among public and private institutions through the creation of a certificate on University Social Responsibility. Social Responsibility should be mandatory in all HEIs, as part of the quality policy through the implementation of the Social Responsibility guide NMX-SA-ST-2600-IMNC, see Figure 1 as a starting point and reference.

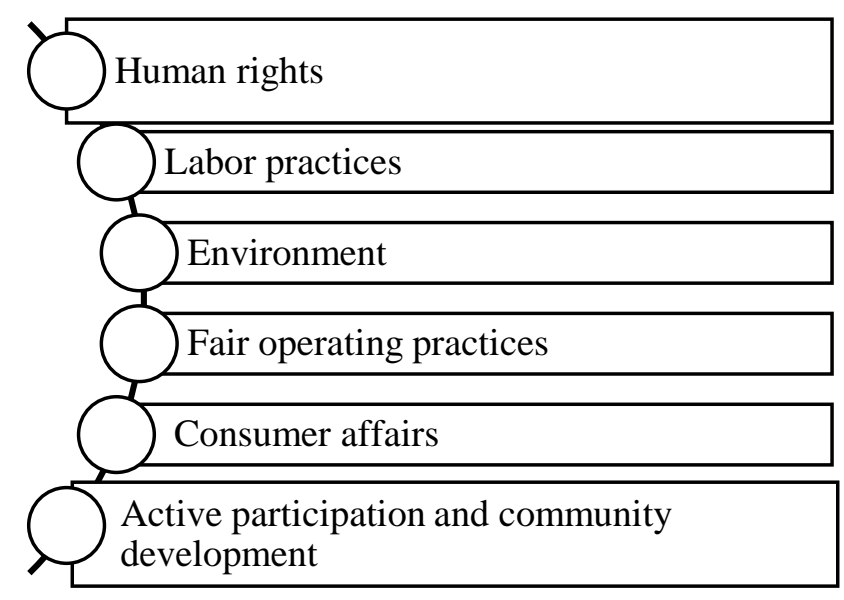

Figure 1 Fundamental subjects oriented towards Social Responsibility

Source: Taken from Norma Mexicana Guía de Responsabilidad Social NMX-SAST_26000-IMNC-2011
The guide aims to lead the strategies, actions for compliance with the principles (accountability, transparency, ethical behavior, respect for the interests of stakeholders, respect for the principle of legality, respect for international standards of behavior and respect for human rights) that govern Social Responsibility and involvement with all stakeholders citizens, government, business, consumers, industry, workers, NGOs, universities, academia, and others.

\section{Proposal}

As can be seen in diagram 1 , the fundamental issues regarding Social Responsibility considered in the guide are, in practice, addressed by each of the institutions interested in promoting a sense of Social Responsibility, including COPAES, ESR, ANFECA, among others.

Likewise, it is important to emphasize that it is within the family that there is a great responsibility, mainly concerning the teaching and guidance of parents towards their children, in coordination with schools, chiefly those of a basic level, since it is during the first years of education that children develop their capacities for integration and care of the environment in order to continue with the education of a higher secondary level and higher education, regulated by the federal government.

Undoubtedly, the Mexican government, as the entity in charge of bringing education closer to society, has a significant role, since through educational policies, and more specifically in the content of its curricula, it has the obligation and responsibility to include subjects related to Social Responsibility.

This is followed by companies that consider themselves as agencies or organizations in charge of producing goods and services to meet the needs of different markets, with the commitment to carry out their different productive activities, but with Social Responsibility, that is, they must be concerned with the care of the environment sustainably among their workers and society.

Finally, society will reflect the whole process of teaching and learning in relation to the sense of Social Responsibility of the children carried out throughout life, as Delors says. 
So that everyone can understand the growing complexity of global phenomena and master the sense of uncertainty that they create. First they must acquire a body of knowledge and then they must learn to put facts into perspective and to be critical of information flows. This is why education is irreplaceable in the formation of judgement. (1997, p.44).

In this sense, the Social Responsibility that is currently being promoted in Higher Education Institutions is, to a certain extent, a change of paradigm. Technological Universities are institutions concerned with the issue in question and have taken essential but insufficient actions to achieve significant changes in the field. This can be constantly observed in the behavior of the acts and duties of each person, professionals, companies, institutions, and even the government, which leave much to be desired, for not fulfilling the mandate of Social Responsibility.

Because of this, the proposal is that the basis of any human behavior, both personal and collective, is the family, in coordination with education from basic to professional, the latter with all its principles and values that give it its reason for being and strength, and the commitment to disseminate and extend knowledge not only to its students, but to society in general, in order to affirm and reaffirm all that baggage of knowledge related to Social Responsibility.

This proposal can be observed in Diagram 2, in which the relationship between the different actors is established until arriving at the society that is another part of the base of Social Responsibility.

There is a need for pedagogical models that impact students with a sense of participation and that promote a change of paradigm, for example, strengthening the social service to which all students are obliged, but not all of them do so. The ISO 26000:2011 standard establishes that the objective of Social Responsibility is to contribute to sustainable development, concepts that are intertwined and to pursue one is to achieve the other, for which it is suggested that from the educational public policy the HEIs can adopt the Guide on Responsibility: ISO 26000 as a starting point and guidance to define actions, activities, and decisions in society and the environment (IMNC, 2011).

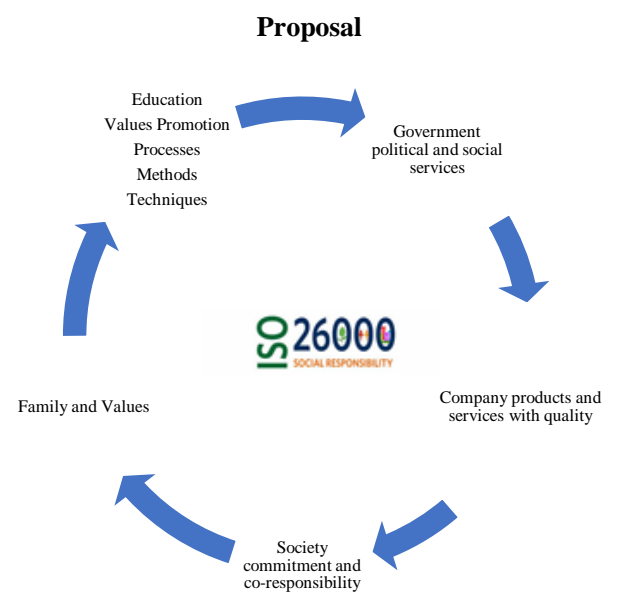

Figure 2 Relationship between the different responsible actors in the promotion of Responsibility

Source: Prepared by the authors

The ISO 26000 is a global guide for the application of best practices in Social Responsibility around the world. It establishes principles and fundamental issues that are the basis for the incorporation of Social Responsibility in the organization, thus fulfilling the following objectives:

a) To support organizations to establish, carry out, maintain and improve the structures of Social Responsibility in four phases, to know their characteristics and their relation with sustainable development; recognition of SR and stakeholders; to apply the seven principles and to consider the eight fundamental matters.

Finally, in order to make Social Responsibility part of the way of life, first of the individuals and then replicated in the different contexts, it is necessary that the educational policy incorporates, in addition to the curriculum maps, topics such as sustainability, corporate social responsibility, business, human rights, beneficial labor practices, accountability, ethical behavior, gender equality, transparency and coexistence values.

\section{References:}

ANFECA (2018) Consulted on December 28, 2018

http://www.anfeca.unam.mx/coordinaciones_re sponsabilidad.php

CGUT. (2017). Distribución cuatrimestral de la carrera TSU Desarrollo de negocios área Mercadotecnia. Plan de estudio vigente. 
CGUT. (2017). Distribución cuatrimestral de la carrera TSU en Administración área Capital Humano Plan de estudio vigente.

CGUT. (2009). Distribución cuatrimestral de la carrera de TSU Desarrollo de negocios área Mercadotecnia.

CGUT. (2009). Distribución cuatrimestral de la carrera de TSU en Administración Área recursos humanos.

CGUT. (2009) Distribución cuatrimestral de la carrera de Ingeniería en Desarrollo e Innovación Empresarial en competencias profesionales, plan de estudio vigente.

CEMEFI (2019) Distintivo ESR, Retrieved February 5, 2019https://www.cemefi.org/esr/

COPAES (2018) Retrieved December 20, 2018 from https://www.copaes.org/acreditacion.php

Delors Jacques (1997) La educación encierra un tesoro, UNESCO, Ed. Dower internacional S.A de C.V

CEPAL. (January, 21, 2013). ENVEJECIMIENTO. Retrieved June 2, 2016, from

www.cepal.org/celade/noticias/noticias/7/23867 /pyden_5.pdf

IMNC (2011) ISO 26000:2010 Guía de Responsabilidad Social,NMX-SAST-26000IMNC-2011 Mexico, DF.

Kliksberg, HNBernardo(s.f) Hacia Un Nuevo Paradigma en Responsabilidad SocialEmpresarial Retrieved January 4, 2019 from

http://www.codigor.com.ar/Hacia\%20Un\%20N uevo\%20Paradigma.pdf

Maritain Jacques (2008) La educación en la encrucijada, Ed. Biblioteca Palabra

Morán, Bravo, L.(2017) Calidad de la Gestión en la Política Educativa del Subsistema de Universidades Tecnológicas, El Caso de la Universidad Tecnológica de Puebla. Tesis de doctorado en Administración Pública.

Münch Galindo, L. (2018) Capital Humano Ed. Trillas
ONU(2015) Transformar Nuestro Mundo: la Agenda 2030 para el Desarrollo Sostenible" Retrieved December 28, 2018 from http://www.onu.org.mx/agenda-2030/

Organización de las Naciones Unidas (ONU) 2018. Pacto Mundial de la organización de las Naciones Unidad. http//www.unglobalcompact.org/Languajes/spa nish/index.html

Rojas, S. R. (2016). Guía para realizar investigaciones sociales. México: Plaza y Valdés.

Torres, Z. (2010) Introducción a la ética, México, grupo editorial patria.

UNESCO(2014) Conferencia Mundial sobre educación para el desarrollo sostenible, Consulted August 20, 2014 en http://www.unesco.org/new/es/unesco-worldconference-on-esd-2014/home/ 